\title{
PENGEMBANGAN PERANGKAT PEMBELAJARAN FISIKA MODEL INKUIRI TERBIMBING UNTUK MELATIHKAN KEMAMPUAN MULTI REPRESENTASI SISWA SMA
}

\author{
Binar Kurnia Prahani' ${ }^{1)}$, Soegimin W. W. ${ }^{2)}$, Leny Yuanita ${ }^{3)}$ \\ ${ }^{1)}$ Program Studi Pendidikan Sains, Program Pascasarjana Universitas Negeri Surabaya \\ ${ }^{2), 3)}$ Dosen Pascasarjana Prodi Pendidikan Sains Univesrtitas Negeri Surabaya \\ E-mail: binarprahani@gmail.com
}

\begin{abstract}
The purpose of this research is produce physics learning material through guided inquiry model that valid, practical, and effective to try multiple representation ability of student in senior high school. The development of learning material used the Kemp model and was tested in class X of SMAN 19 Surabaya second semester in academic year 2013/2014 with One-Group Pretest-Posttest Design. The data collection used observation method, test, and quetionnaires. The data analysis techniques used descriptive analysis of quantitative, qualitative and statistic non parametric. The results of this research are: 1) Learning material developed has a valid category; 2) Learning material in terms of a practical category in feasibility of lesson plans and the students' activities in accordance with steps of guided inquiry model; and 3) The learning material effectiveness in terms of: (a) Improving students' learning achievement seen from the n-gain score with high category; (b) Improving multiple representation ability of student by getting the n-gain score with high category and the analysis results of statistic non parametric are: 1) nothing different of multiple representation ability of student at each class, 2) different of multiple representation ability of student, and 3) nothing different of improving multiple representation ability of student at each class; and (c) The students' responds toward material and implementation of learning are very positive. It's conclusion that the learning material through guided inquiry model are valid, practical, and effective to try multiple representation ability of student in senior high school.
\end{abstract}

\section{Keywords: Learning Material, Guided Inquiry, Multiple Representation}

\begin{abstract}
Abstrak : Penelitian ini bertujuan untuk menghasilkan perangkat pembelajaran fisika model inkuiri terbimbing yang valid, praktis, dan efektif untuk melatihkan kemampuan multi representasi siswa SMA. Pengembangan perangkat pembelajaran menggunakan model Kemp dan diujicobakan di kelas X SMAN 19 Surabaya semester genap tahun ajaran 2013/2014 dengan One-Group Pretest-Posttest Design. Pengumpulan data menggunakan metode observasi, tes, dan angket. Teknik analisis data menggunakan analisis deskriptif kuantitatif, kualitatif dan uji statistik non parametrik. Hasil penelitian ini menunjukkan,: 1) Perangkat pembelajaran yang dikembangkan berkategori valid; 2) Perangkat pembelajaran ditinjau dari keterlaksanaan RPP berkategori praktis dan aktivitas siswa sesuai dengan tahap-tahap pada model inkuiri terbimbing; dan 3) Keefektifan perangkat pembelajaran ditinjau dari: (a) Peningkatan hasil belajar siswa terlihat dari n-gain dengan kategori tinggi; (b) Peningkatan penguasaan kemampuan multi representasi siswa terlihat dari n-gain dengan kategori tinggi dan hasil analisis uji statistik non parametrik, yaitu: 1) tidak terdapat perbedaan kemampuan multi representasi awal siswa pada kelas yang satu dengan kelas yang lain, 2) terdapat peningkatan kemampuan multi representasi siswa, dan 3) tidak terdapat perbedaan peningkatan kemampuan multi representasi siswa pada kelas yang satu dengan kelas yang lain; dan (c) Respon siswa terhadap perangkat dan pelaksanaan pembelajaran sangat positif. Disimpulkan bahwa perangkat pembelajaran model inkuiri terbimbing yang dikembangkan valid, praktis, dan efektif untuk melatihkan kemampuan multi representasi siswa SMA.
\end{abstract}

Kata kunci: Perangkat Pembelajaran, Inkuiri Terbimbing, Multi Representasi

\section{PENDAhuluan}

Fisika merupakan cabang Ilmu Pengetahuan Alam (IPA). Fisika adalah jantung dari perkembangan teknologi informasi dan komunikasi telah mengubah secara mendasar kehidupan manusia. Berdasarkan pandangan global dan historis, ilmu fisika menyediakan metode lebih dinamis dalam membantu manusia menyelesaikan masalah kehidupan yang kompleks. Pada kenyataannya ditemukan banyak siswa belajar fisika tidak tertarik dan tidak memiliki pemahaman setelah belajar fisika (Prahani, dkk., 2014; David, et al., 2013; Coletta, et al., 2012; Nieminen, et al., 2010;
Benckert \& Pettersson, 2008). Jika ditinjau dari pendapat siswa, maka pendidik diwajibkan menyajikan pembelajaran fisika bermakna dan generasi muda tertarik mempelajarinya.

Kompetensi siswa dibentuk ketika siswa terlibat aktif dalam aktivitas mental, fisik, dan sosialnya. Pada SKL mata pelajaran fisika mengisyaratkan pembelajaran harus bersifat student centered berbasis kegiatan ilmiah. Siswa memerlukan penghayatan dari sikap, pengetahuan, dan keterampilan yang mereka dapat dari pembelajaran kemudian menyesuaikan terhadap pengalaman-pengalaman mereka melalui multi 
representasi. Peserta didik akan belajar lebih efektif dan efisien ketika mereka aktif untuk mengolah informasi dengan multi representasi (David, et al., 2013; Nieminen, et al., 2012; Mahardika, 2012; Abdurrahman, dkk., 2011; Schnotz, et al., 2010; dan Waldrip, et al., 2010).

Berdasarkan tes kemampuan multi representasi di SMA Negeri 19 Surabaya pada sampel 32 siswa kelas $\mathrm{X}$ yang menyelesaikan dengan benar permasalahan fisika sub pokok bahasan pengaruh kalor terhadap wujud zat secara multi representasi hanya $12.50 \%$. Hasil observasi melalui wawancara dan angket pada siswa dan guru ditemukan beberapa penyebab belum terlaksana secara maksimal upaya melatihkan kemampuan multi representasi dalam pembelajaran fisika, yaitu: (1) Keterbatasan waktu guru mata pelajaran fisika untuk dapat menyediakan perangkat pembelajaran dalam melatih kemampuan multi representasi siswa; (2) Siswa mengalami kesulitan menggunakan kemampuan multi representasi fisika; dan (3) Guru bidang studi fisika kesulitan menangani siswa dengan kemampuan rendah dapat aktif dan termotivasi belajar fisika. Guru fisika idealnya harus memahami fisika secara konseptual dan mendalam, mampu melakukan penalaran kualitatif maupun kuantitatif, memahami dan mampu mengembangkan multi representasi, serta memiliki keterampilan dalam inkuiri sains, dan mampu mengantisipasi kesulitan konseptual yang dialami siswa (McDermott, 2004).

Pada pembelajaran fisika peserta didik perlu dilatih untuk mengembangkan kemampuan multi representasi. Multi representasi merupakan salah satu metode yang baik dan sedang berkembang untuk menanamkan pemahaman konsep, penyelesaian masalah fisika dan kesulitan yang disebabkan karena banyaknya keterlibatan gambaran mental (David, et al., 2013; Nieminen, et al., 2013; Bryce, 2012). Heuvelen \& Zou (2001), Meltzer (2005), dan Kohl \& Finkelstein (2008) menyatakan bentuk dari kemampuan multi repesentasi fisika adalah kemampuan untuk menyelesaikan masalah-masalah fisika dengan proses representasi yang bermacam cara yaitu matematis, verbal (tulisan atau oral), dan visual (notasi, gambar, dan grafik). Fungsi utama multi representasi dalam pembelajaran bagi siswa, yaitu: sebagai pelengkap proses kognitif, pembatas interpretasi antar representasi, dan pembangun pemahaman (Ainsworth, 2006; 1999). Permasalahan mengenai kurangnya kemampuan multi representasi siswa menyelesaikan permasalahan fisika dapat diatasi dengan memberikan pengalaman baru yang menantang bagi siswa (Putri, dkk., 2012; Acevedo, et al., 2010). Tantangan dalam pembentukan kemampuan multi representasi dapat dicapai dengan menggunakan model inkuiri (Mahardika, dkk., 2012; David, 2006).
Berdasarkan kurikulum 2013 pada materi kalor diwajibkan untuk merencanakan dan melaksanakan percobaan untuk menyelidiki karakteristik termal suatu bahan, terutama kapasitas kalor. Siswa membutuhkan kemampuan multi representasi untuk melakukan kegiatan ilmiah dan mengembangkan kemampuan sains (Waldrip, et al., 2010). Salah satu pembelajaran untuk kegiatan penyelidikan dalam pembelajaran materi kalor adalah model pembelajaran inkuiri. Model pembelajaran inkuiri terbimbing sebagai alternatif perlu dikembangkan untuk mencapai kompetensi dasar topik kalor dan melatihkan kemampuan multi representasi siswa melalui penyelidikan dan bimbingan. Kohl dan Finkelstein (2008) menyatakan pembelajaran yang dapat melatihkan kemampuan multi representasi adalah penyelidikan (inquiry) dan bimbingan. Setiap langkah dalam model inkuiri membutuhkan kemampuan representasi. Ketika siswa mampu menggunakan kemampuan multi representasi secara maksimal diharapkan dapat memudahkan untuk menyelesaikan permasalahan pada materi kalor.

Model pembelajaran inkuiri terbimbing terdiri dari enam tahap, yaitu: (a) perencanaan, (b) mendapatkan informasi, (c) memproses informasi, (d) membuat informasi, (e) mengkomunikasikan informasi, dan (f) mengevaluasi (Branch \& Oberg, 2004). Pembelajaran inkuiri terbimbing memberi kesempatan para siswa membangun pengetahuan secara multi representasi dan membantu siswa mengembangkan pemahaman konsep (Pandey, et al., 2011; Stricklyn, 2011; Lee, et al., 2010; Minner, et al., 2010; Wilson, et al., 2010; dan David, 2006).

Kemampuan representasi matematik dan verbal diperlukan dalam inkuiri antara lain untuk: mengabstraksikan dari data analisis ke konsep diperlukan kesebandingan matematik, memecahkan soal diperlukan hitungan matematik yang tepat, memahami definisi, saat berdiskusi, menyusun kalimat, mengkomunikasikan, mengartikan, merumuskan dan mengkomunikasikan hasil kesimpulan (Maliyah, dkk., 2012). Penggunaan model inkuiri terbimbing diharapkan dapat melatihkan multi representasi khususnya pada setiap fase model inkuiri terbimbing. Pada tahap mengkomunikasikan informasi siswa dituntut untuk menggunakan semua pengetahuan direpresentasikan dalam berbagai representasi agar hasil proses inkuri dapat disajikan secara valid (David, 2006). Setelah siswa melakukan penyelidikan, pada tahap evaluasi siswa diberikan soal tes kemampuan multi representasi fisika untuk melihat penguasaan kemampuan multi representasi fisika siswa. Hasil penelitian Kohl dan Finkelstein (2008; 2007) menyatakan bahwa siswa belum ahli masih membutuhkan bimbingan ketika penyelesaian masalah menggunakan multi representasi dalam membangun 
deskripsi verbal, visual, dan matematis pada kegiatan penyelidikan (inkuiri).

Siswa harus memperoleh pemahaman konsep dan membutuhkan kegiatan pembelajaran yang dapat menyajikan konsep yang mereka miliki secara utuh dengan multi representasi (Nieminen, et al., 2011; Cook, 2006; Jong, et al., 2010; Larkin \& Simon, 1987; Meij \& Jong, 2006). Hasil penelitian Putri, dkk. (2012) menyimpulkan melalui kegiatan inkuiri dapat mengatasi kurangnya kemampuan multi representasi siswa dalam menyelesaikan permasalahan fisika. Maliyah, dkk. (2012) menyimpulkan bahwa pembelajaran inkuiri terbimbing pada materi suhu dan kalor berpengaruh terhadap kemampuan representasi dan prestasi belajar siswa SMA. Mahardika, dkk. (2012) dan David (2006) menyimpulkan model inkuiri dapat meningkatkan kemampuan multi representasi dan hasil belajar fisika siswa SMA. Kemampuan multi representasi fisika telah diteliti di negara lain diantaranya oleh: Dolin (2001), Heuvelen \& Xueli (2001), Meltzer (2005), Kohl \& Finkelstein (2008; 2007; 2006; 2005), Nieminen, et al. (2013; 2012; 2011; 2010), Schnot, et al. (2010), dan Waldrip, et al. (2010; 2006). Penelitian lebih lanjut khususnya terhadap materi kalor pada siswa SMA berdasarkan kurikulum 2013 yang mengacu untuk melatihkan kemampuan multi representasi menggunakan model inkuri terbimbing sangat perlu dilaksanakan.

Berdasarkan penjelasan di atas maka dipilih model inkuiri terbimbing untuk melatihkan kemampuan multi representasi fisika siswa SMA Negeri 19 Surabaya pada materi kalor. Peneliti akan merancang dan melakukan penelitian berjudul "Pengembangan Perangkat Pembelajaran Fisika Model Inkuiri Terbimbing untuk Melatihkan Kemampuan Multi Representasi Siswa SMA".

Secara umum, tujuan penelitian ini adalah untuk menghasilkan perangkat pembelajaran fisika model inkuiri terbimbing yang valid, praktis, dan efektif untuk melatihkan kemampuan multi representasi siswa SMA.

\section{METODE PENELITIAN}

Penelitian ini merupakan penelitian pengembangan. Penelitian ini mengembangkan perangkat pembelajaran fisika SMA dengan model inkuiri terbimbing pada materi kalor untuk melatihkan kemampuan multi representasi. Penelitian pengembangan ini mengacu pada model pengembangan Kemp, et al. (2007). Model pengembangan tersebut terdiri atas: 1) Instructional problems; 2) Learner characteristics; 3) Task analysis; 4) Instructional objectives; 5) Content sequencing; 6) Instructional strategies; (7) Instructional delivery; 8) Evaluation instrumens; dan 9) Instructional resources. Perangkat pembelajaran yang dihasilkan meliputi Rencana
Pelaksanaan Pembelajaran (RPP), Lembar Kegiatan Siswa (LKS), buku ajar materi kalor, instrumen penilaian hasil belajar dan instrumen tes kemampuan multi representasi.

Subjek penelitian dari penerapan hasil pengembangan perangkat pembelajaran model inkuiri terbimbing pada materi kalor pada uji coba adalah siswa kelas X SMA Negeri 19 Surabaya tahun pelajaran 2013/2014. Pada uji coba I melibatkan 13 siswa dan uji coba II sebanyak 93 siswa pada 3 kelas.

Rancangan uji coba digunakan untuk mengujicobakan hasil pengembangan perangkat pembelajaran fisika model inkuiri terbimbing. Rancangan penelitian menggunakan rancangan onegroup pretest-posttest design. Rancangan penelitian ini melibatkan satu kelompok yang diobservasi pada tahap pretest $\left(O_{I}\right)$ yang kemudian dilanjutkan dengan perlakuan tertentu $(X)$ dan posttest $\left(O_{2}\right)$ (Sugiyono, 2014).

\section{$\mathrm{O}_{1} \times \mathrm{O}_{2}$}

Dengan:

$O_{l}$ adalah uji awal (pretest) untuk mengetahui penguasaan siswa terhadap materi pelajaran sebelum pembelajaran.

$\mathrm{O}_{2}$ adalah uji awal (posttest) untuk mengetahui penguasaan siswa terhadap materi pelajaran sesudah pembelajaran.

$X$ adalah perlakuan pembelajaran dengan menggunakan perangkat pembelajaran model inkuiri terbimbing.

Pengembangan perangkat pembelajaran dalam penelitian ini mengadopsi sembilan unsur dari model pengembangan Kemp, et al. (2007). Pemilihan model ini dikarenakan tiap-tiap langkah pengembangannya berhubungan langsung dengan aktivitas revisi dan dapat dimulai dari tahap manapun sesuai dalam siklus tersebut. Kurikulum yang berlaku secara nasional di Indonesia berorientasi pada tujuan, maka proses pengembangan perangkat pembelajaran pada penelitian ini dimulai dari tujuan dan berakhir pada evaluasi.

Keseluruhan prosedur pada penelitian ini dibagi menjadi tiga tahap yaitu:

1) Tahap pertama pengembangan, revisi I, dan validasi perangkat pembelajaran yang meliputi rencana pelaksanaan pembelajaran, lembar kegiatan siswa, buku ajar, instrumen aspek pengetahuan, instrumen penilaian tes kinerja, instrumen penilaian sikap siswa, dan instrumen penilaian kemampuan multi representasi.

2) Tahap kedua adalah mengujicobakan perangkat yang telah dikembangkan dengan jumlah siswa yang terbatas (13 siswa).

3) Tahap ketiga adalah revisi II dan membuat laporan komprehensif. 
4) Tahap keempat adalah mengujicobakan perangkat yang telah dikembangkan dengan 3 replikasi (93 siswa).

Langkah-langkah pengembangan perangkat pembelajaran dengan model inkuiri terbimbing dideskripsikan pada diagram alur pada Gambar 1.

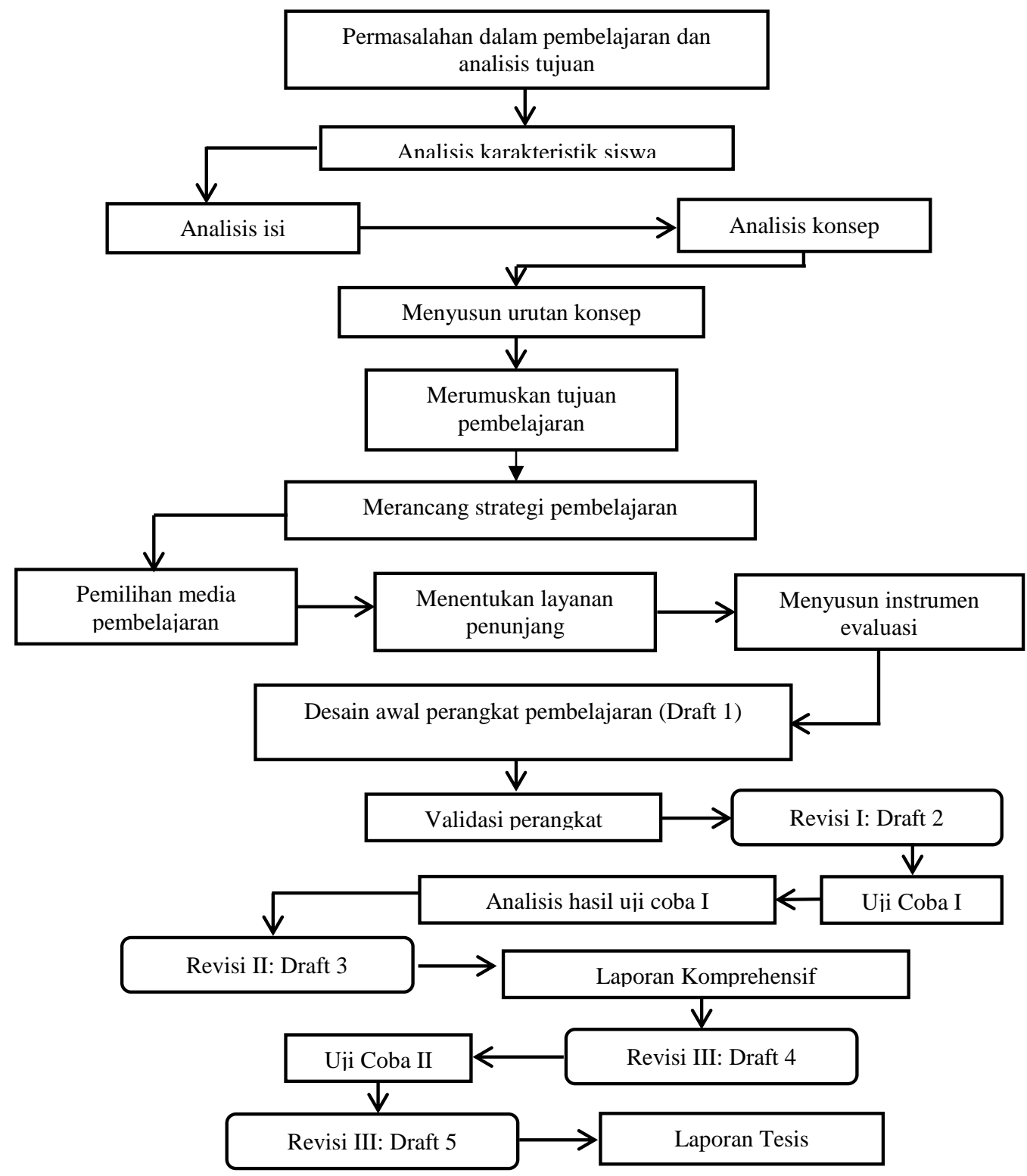

Gambar 1 Diagram alur pengembangan perangkat pembelajaran yang digunakan peneliti adaptasi dari model Kemp (2007)

Teknik pengumpulan data digunakan untuk memperoleh bahan-bahan yang relevan, akurat, dan dapat digunakan dengan tepat sesuai tujuan penelitian. Teknik pengumpulan data yang digunakan dalam penelitian ini adalah: (1) pengamatan; (2) tes; (3) dokumentasi; dan (4) angket.

\section{Teknik Analisis Data}

Analisis hasil pengembangan perangkat pembelajaran dan hasil ujicoba perangkat pembelajaran fisika yang menggunakan model
Tahap kelima adalah revisi III dan membuat laporan tesis. 
Teknik analisis data keterlaksanaan pembelajaran menggunakan deskriptif kuantitatif dan kualitatif. Nilai dari keterlaksanaan pembelajaran yang dilakukan oleh dua pengamat yang sudah memahami lembar pengamatan secara benar, kemudian data diolah dengan menghitung dengan menggunakan persamaan sebagai berikut:

$P=\frac{\text { Jumlah tahap pembelajaran yang dilaksanakan }}{\text { jumlah seluruh tahap pembelajaran }} \times 100 \%$

Pelaksanaan pengamatan masing-masing pengamat memberikan penilaian (4: baik, 3: cukup baik, 2: kurang baik, dan 1: tidak baik). Kriteria penilaian yang diperoleh dengan membandingkan ratarata skala penilaian diberikan kedua pengamat dengan kriteria penilaian di bawah ini:
$1.00-1.49$
: Tidak baik
$1.50-2.49$
: Kurang baik
$2.50-3.49$
: Cukup baik
$3.50-4.00$
: Baik

(Ratumanan \& Laurens, 2011)

\section{3) Analisis Aktivitas Siswa}

Teknik analisis data pengamatan aktivitas siswa menggunakan deskriptif kuantitatif dan kualitatif. untuk memberikan deskripsi aktivitas siswa selama kegiatan pembelajaran dengan model pembelajaran inkuiri terbimbing. Data hasil pengamatan aktivitas siswa selama kegiatan pembelajaran dianalisis dengan menggunakan persentase. Rumus persentase aktivitas siswa dapat disajikan dalam bentuk persamaan berikut.

$$
\mathrm{P}=\frac{\sum R}{\sum N} x 100 \%
$$

Keterangan :

$P$ : persentase aktivitas siswa

$\sum R: \quad$ jumlah frekuensi kategori pengamatan

$\Sigma N$ : jumlah frekuensi seluruh kategori pengamatan

(Arifin, 2010)

4) Analisis Kemampuan Multi Representasi Fisika

Teknik analisis peningkatan kemampuan multi representasi fisika siswa menggunakan deskriptif kualitatif dan statistik inferensial non parametrik Analisis kemampuan multi representasi fisika siswa dapat dihitung dengan menggunakan persamaan sebagai berikut:

$K M R=\frac{\text { jumlah skor yang diperoleh }}{\text { jumlah skor maksimum }} \times 100$

Keterangan: KMR = Kemampuan Multi Representasi

Ketika nilai minimal siswa mencapai 75 disetiap kemampuan representasi (matematis, visual, dan matematis), maka siswa dinyatakan sudah mencapai kemampuan multi representasi (Mahardika, 2012)
Kemampuan multi representasi siswa setelah kegiatan pembelajaran diukur mengunakan instrumen tes kemampuan multi representasi.

$N$-gain menunjukkan peningkatan kemampuan multi representasi fisika siswa sebelum dan setelah perlakuan.

$\langle g\rangle=\frac{\text { Spost }- \text { Spre }}{S \text { max }- \text { Spre }}$

Dengan :

$\langle g\rangle$

: Nilai gain

Spost : Nilai posttest

Spre : Nilai pretest

Smax : Nilai maksimal

Selanjutnya dari hasil perhitungan $n$-gain tersebut kemudian dikonversi dengan kriteria sebagai berikut:

Tabel 1. Kriteria normalized gain

\begin{tabular}{|c|c|}
\hline Skor $N$-Gain & Kriteria Normalized Gain \\
\hline $0.70<N$-Gain & Tinggi \\
\hline $0.30 \leq N$-Gain $\leq 0.70$ & Sedang \\
\hline$N$-Gain $<0.30$ & Rendah \\
\hline
\end{tabular}

(Hake, 1999)

Kemampuan multi representasi siswa setelah diberikan perlakuan menggunakan model inkuiri terbimbing, dilakukan analisis statistik inferensial dengan SPSS 20 sebagai berikut:

Uji perbedaan pretest dan posttest dilakukan pada kelas X1, X2 dan X3 menggunakan statistik inferensial non parametrik dengan taraf signifikansi $\alpha=0.05$ tailed).

1) Perbedaan Kemampuan Multi Representasi Awal Siswa

Untuk mengetahui persamaan pemahaman awal siswa menggunakan uji U Mann-Whitney pada data pretest dengan hipotesis sebagai berikut:

$H_{0}$ : Tidak terdapat perbedaan kemampuan multi representasi awal siswa pada kelas yang satu dengan kelas yang lain.

$H_{1}$ : Terdapat perbedaan kemampuan multi representasi awal siswa pada kelas yang satu dengan kelas yang lain.

Pada pengujian hipotesis kriteria untuk menolak atau tidak menolak $\mathrm{H}_{0}$ berdasarkan $\mathrm{P}$-value adalah sebagai berikut:

Jika $\mathrm{P}$-value $<\alpha$, maka $H_{0}$ ditolak

Jika $\mathrm{P}-$ value $\geq \alpha$, maka $H_{0}$ tidak dapat ditolak (Sugiyono, 2014)

2) Peningkatan Kemampuan Multi Representasi Siswa

Peningkatan kemampuan multi representasi siswa secara signifikan untuk setiap kelas dapat ditentukan 
mengunakan uji Wilcoxon matched pairs pada data pretest dan posttest dengan hipotesis sebagai berikut:

$H_{0}$ : Tidak terdapat peningkatan kemampuan multi representasi siswa.

$H_{I}$ : Terdapat peningkatan kemampuan multi representasi siswa.

Jika P-value $<\alpha$, maka $\mathrm{H}_{0}$ ditolak

Jika $\mathrm{P}$ - value $\geq \alpha$, maka $\mathrm{H}_{0}$ tidak dapat ditolak (Sugiyono, 2014)

3) Perbedaan Peningkatan Kemampuan Multi Representasi Siswa

Persamaan kemampuan multi representasi siswa antara kelas yang satu dengan yang lain ditentukan dengan menggunakan uji U Mann-Whitney pada data gain ternormalisasi (n-gain) dengan hipotesis sebagai berikut:

$H_{0}$ : Tidak terdapat perbedaan peningkatan kemampuan multi representasi siswa pada kelas yang satu dengan kelas yang lain.

$H_{l}$ :Terdapat perbedaan peningkatan kemampuan multi representasi siswa pada kelas yang satu dengan kelas yang lain.

Jika P-value $<\alpha$, maka $\mathrm{H}_{0}$ ditolak

Jika $\mathrm{P}$ - value $\geq \alpha$, maka $\mathrm{H}_{0}$ tidak dapat ditolak (Sugiyono, 2014)

\section{4) Analisis untuk Data Respon Siswa}

Data tentang respon siswa diperoleh dari angket respon siswa terhadap kegiatan pembelajaran, dan selanjutnya dianalisis dengan menggunakan deskriptif kualitatif. Data respon yang diperoleh digunakan menindaklanjuti kegiatan pembelajaran dengan menggunakan model inkuiri terbimbing. Analisis data angket respon siswa menggunakan skala Guttman. Siswa menjawab Ya bernilai (1) dan siswa menjawab Tidak bernilai (0). Data dianalisis berdasarkan kelompok responden yang menjawab "Ya" dan kelompok responden yang menjawab "Tidak". Secara matematis dapat ditulis sebagai berikut:

$$
P=\frac{\sum K}{\sum N} \times 100 \%
$$

Keterangan:

$P \quad:$ Persentase skor respon siswa

$\sum K$ : Jumlah siswa yang memilih jawaban $\mathrm{Ya}$ atau Tidak

$\sum N$ : Jumlah siswa yang mengisi angket

Persentase respon siswa dikonversi dengan kriteria sebagai berikut:

Angka $0 \%-20 \% \quad=$ Sangat lemah

Angka $21 \%-40 \% \quad=$ Lemah

Angka $41 \%-60 \%$ = Cukup

Angka $61 \%-80 \% \quad=$ Kuat
Angka $81 \%-100 \% \quad=$ Sangat kuat

(Riduwan, 2010)

\section{HASIL PENELITIAN DAN DISKUSI}

\section{A. Hasil Pengembangan Perangkat Pembelajaran}

Hasil pengembangan perangkat pembelajaran fisika model inkuiri terbimbing yang dikembangkan valid untuk digunakan dalam pembelajaran fisika untuk melatihkan kemampuan multi representasi.

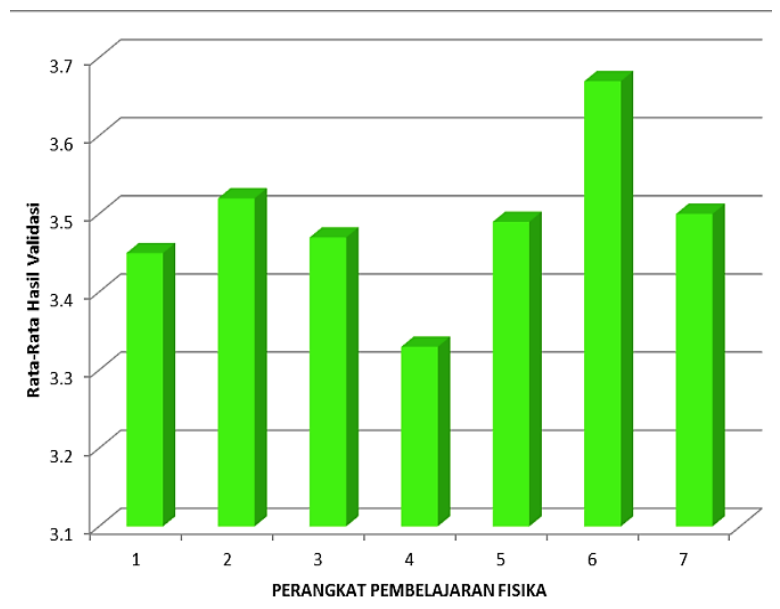

Gambar 2. Hasil validasi pengembangan perangkat pembelajaran fisika

Keterangan:
1. RPP
2. LKS
3. Buku Ajar
4. Instrumen Tes Pengetahuan
5. Instrumen Tes Kinerja
6. Instrumen Sikap
7. Instrumen Tes Multi Representasi

\section{B. Kepraktisan Perangkat Pembelajaran}

1) Keterlaksanaan RPP

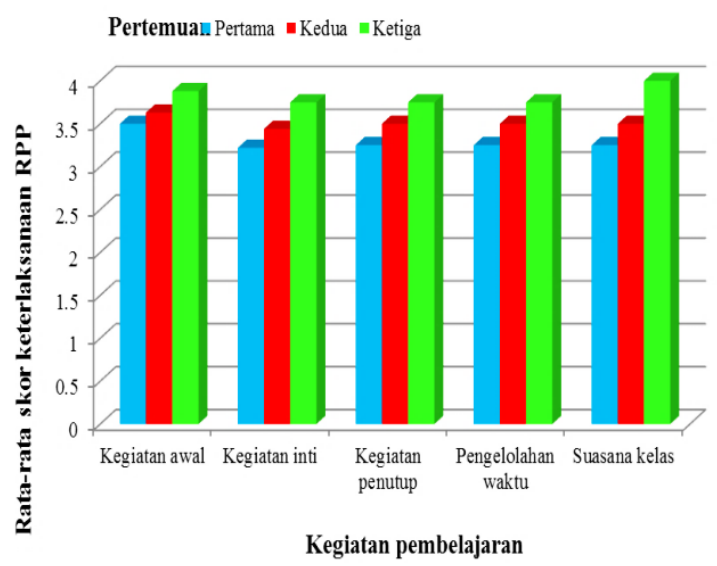

Gambar 3. Keterlaksanaan RPP di kelas X1

Semua tahap-tahap kegiatan yang ada di dalam RPP di kelas X1 terlaksana dan secara rata-rata keseluruhan skor keterlaksanaannya adalah 3.65 dengan kategori baik. dan rata-rata reliabilitas $96.19 \%$ 
Semua tahap-tahap kegiatan yang ada di dalam RPP di kelas X2 terlaksana dan secara rata-rata keseluruhan skor keterlaksanaannya adalah 3.54 dengan kategori baik. dan rata-rata reliabilitas $94.79 \%$

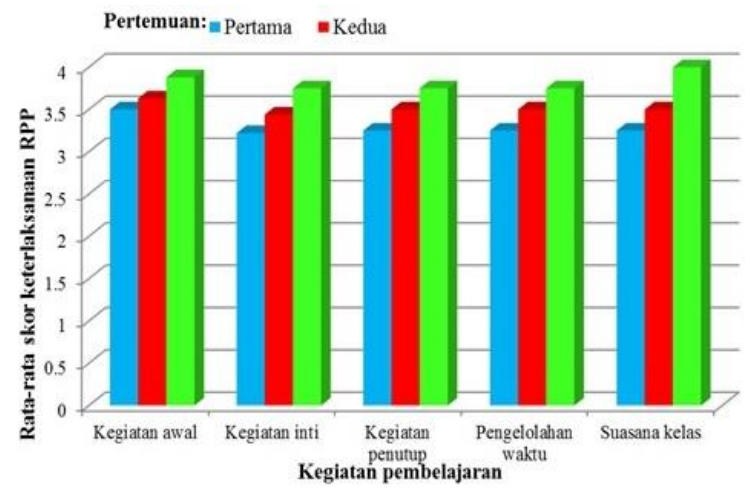

Gambar 4. Keterlaksanaan RPP di kelas X2

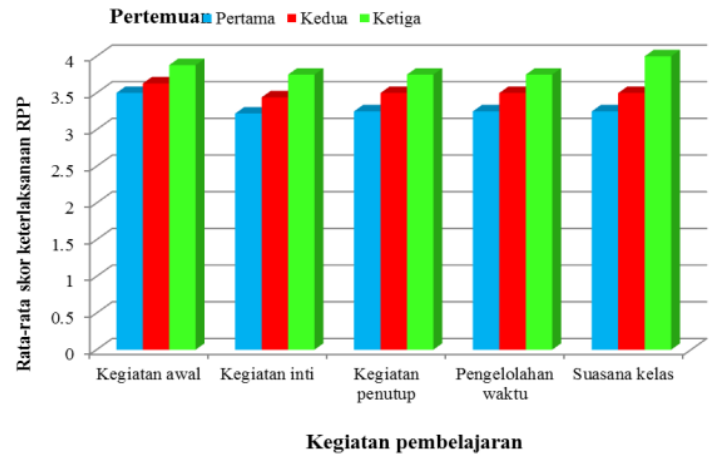

Gambar 5. Keterlaksanaan RPP di kelas X3

Semua tahap-tahap kegiatan yang ada di dalam RPP di kelas X3 terlaksana dan secara rata-rata keseluruhan skor keterlaksanaannya adalah 3.51 dengan kategori baik. dan rata-rata reliabilitas $95.13 \%$.

Keterlakasanaan RPP 1, RPP 2, dan RPP 3 pada kelas X SMAN 19 Surabaya dalam proses pembelajaran dengan dua replikasi secara rata-rata keseluruhan skor keterlaksanaannya adalah 3.60 berkategori baik.

Aktivitas siswa pada uji coba II sesuai dengan tahap-tahap pada model inkuiri terbimbing. Hasil pengamatan aktivitas siswa pada uji coba II dengan tiga replikasi diketahui bahwa pada aktivitas memperhatikan penjelasan, menjawab pertanyaan guru, merumuskan rumusan masalah dan hipotesis percobaan, menentukan variabel percobaan, menjawab dan menanggapi pertanyaan diskusi, merumuskan kesimpulan hasil percobaan, menyajikan dan mengkomunikasikan hasil percobaan secara multi representasi, mengerjakan soal kemampuan multi representasi mengalami peningkatan di tiap pertemuan. Aktivitas yang menonjol adalah merancang dan melakukan percobaan, menganalisis data hasil percobaan secara multi representasi di tiap pertemuan. Aktivitas bertanya kepada guru mengenai bimbingan dan tindakan yang tidak relevan mengalami penurunan di tiap pertemuaan. Berdasarkan hasil di atas dapat disimpulkan bahwa aktivitas siswa sudah sesuai dengan tahap-tahap model inkuri terbimbing untuk melatihkan kemampuan multi representasi.

Keefektifan perangkat pembelajaran melalui implementasi dengan tiga replikasi di kelas $\mathrm{X} 1, \mathrm{X} 2$, $\mathrm{X} 3$ dilihat dari:

a. Penerapan perangkat pembelajaran fisika model inkuiri terbimbing dapat melatihkan kemampuan multi representasi siswa. Peningkatan kemampuan multi representasi dapat dilihat dari n-gain dari ketiga kelas replikasi diperoleh $n$-gain rata-rata dari kelas X1, X2, dan X3 adalah sebesar 0.78, 0.75, dan 0.78 dengan kategori tinggi. Berdasarkan hasil analisis statistik non parametrik, yaitu: 1) Pada kelas X1 dan X2; kelas X1 dan X3; kelas X2 dan $\mathrm{X} 3$ tidak terdapat perbedaan kemampuan multi representasi awal siswa pada kelas yang satu dengan kelas yang lain.; 2) Pada kelas X1, X2, dan X3 terdapat peningkatan kemampuan multi representasi siswa; dan 3) Pada kelas X1 dan X2, kelas X1 dan X3, kelas X2 dan X3 tidak terdapat perbedaan peningkatan kemampuan multi representasi siswa pada kelas yang satu dengan kelas yang lain.

b. Siswa merespon sangat positif hasil pengembangan perangkat dan pelaksanaan pembelajaran dengan model inkuiri terbimbing. Hal tersebut dapat dilihat dari hasil analisis data respon siswa sebanyak 88.98\% siswa merespon dengan kriteria sangat kuat.

Berdasarkan hasil di atas dapat disimpulkan bahwa perangkat pembelajaran model inkuri terbimbing yang telah dikembangkan efektif untuk melatihkan kemampuan multi representasi siswa SMA.

Berdasarkan penerapan hasil pengembangan perangkat dapat meningkatkan kemampuan multi representasi dengan $n$-gain rata-rata dari kelas $\mathrm{X} 1, \mathrm{X} 2$, dan X3 adalah sebesar 0.78, 0.75, dan 0.78 dengan kategori tinggi (Hake, 1999). Berdasarkan rata-rata ketuntasan tujuan pembelajaran kemampuan multi representasi pada uji coba II kelas X1, X2, dan X3 sebesar 93.55\%, 77.25\%, dan 95.93\%. Aspek kemampuan multi representasi yang paling tinggi terdapat para representasi matematis dan yang terendah pada representasi verbal.

Uji normalitas data pretest dan posttest kemampuan multi representasi menggunakaan uji Shapiro-Wilk dengan taraf signifikansi $\alpha=0.05$ (2tailed). Hasil uji normalitas diperoleh data pretest dan posttest pada kelas $\mathrm{X} 1, \mathrm{X} 2$, dan $\mathrm{X} 3$ nilai sig. $<0.05$, hal ini berarti data pretest dan posttest berdistribusi tidak normal. Hasil uji normalitas diperoleh data $n$ - 
gain pada kelas $\mathrm{X} 1$ dan $\mathrm{X} 2$ nilai sig. $<0.05$, hal ini berarti data $n$-gain pada kelas X1 dan X2 berdistribusi tidak normal. Pada kelas X3 nilai sig. $>0.05$, hal ini berarti data $n$-gain pada kelas X3 berdistribusi normal.

Uji Perbedaan Kemampuan Multi Representasi Siswa

1) Perbedaan Kemampuan Multi Representasi Awal Siswa

Uji perbedaan kemampuan multi representasi awal siswa menggunakan data pretest kemampuan multi representasi menggunakaan uji Mann-Whitney U dengan taraf signifikansi $\alpha=0.05$ (2-tailed).

Tabel 2 Hasil uji U Mann-Whitney pada data pretest

\begin{tabular}{|c|c|c|c|c|c|}
\hline $\begin{array}{c}\text { Sam } \\
\text { pel }\end{array}$ & $\begin{array}{c}M e a \\
n\end{array}$ & $\begin{array}{c}\text { Std. } \\
\text { Deviatio } \\
n\end{array}$ & $\begin{array}{c}\text { Mann- } \\
\text { Whitney U }\end{array}$ & $Z$ & $\begin{array}{c}\text { Asymp. } \\
\text { Sig. } \\
\text { (2-tailed) }\end{array}$ \\
\hline $\begin{array}{c}\text { Pret } \\
\text { est } \\
\mathrm{X} 1 \\
\text { dan } \\
\mathrm{X} 2\end{array}$ & $\begin{array}{c}6.64 \\
6 \\
1.50 \\
7\end{array}$ & $\begin{array}{c}1.77045 \\
.50395\end{array}$ & 404.000 & $\begin{array}{c}1.32 \\
4\end{array}$ & .185 \\
\hline $\begin{array}{c}\text { Pret } \\
\text { est } \\
\mathrm{X} 1 \\
\text { dan } \\
\mathrm{X} 3\end{array}$ & $\begin{array}{c}7.18 \\
1 \\
1.98 \\
3\end{array}$ & $\begin{array}{l}1.24238 \\
1.00816\end{array}$ & 394.000 & $\begin{array}{c}- \\
1.11 \\
7\end{array}$ & .264 \\
\hline $\begin{array}{l}\text { Pret } \\
\text { est } \\
\mathrm{X} 2 \\
\text { dan } \\
\mathrm{X} 3\end{array}$ & $\begin{array}{c}6.67 \\
8 \\
2.48 \\
3\end{array}$ & $\begin{array}{c}1.92054 \\
.50382\end{array}$ & 438.000 & $\begin{array}{c}- \\
1.07 \\
8\end{array}$ & .281 \\
\hline
\end{tabular}

Pada kelas X1 dan X2; kelas X1 dan X3; dan kelas X2 dan X3 nilai sig. > 0.05, hal ini berarti tidak terdapat perbedaan kemampuan multi representasi awal siswa pada kelas yang satu dengan kelas yang lain.

2) Peningkatan Kemampuan Multi Representasi Siswa

Uji peningkatan kemampuan multi representasi siswa menggunakan data pretest dan posttest kemampuan multi representasi tiap kelas menggunakan uji Wilcoxon matched pairs dengan taraf signifikansi $\alpha=0.05$ (2-tailed) pada Tabel 4.33 dan Lampiran 2x.

Tabel 3 Hasil uji Wilcoxon matched pairs pada data pretest dan posttest

\begin{tabular}{|c|c|c|c|c|}
\hline $\begin{array}{c}\text { Data } \\
\text { Pretest- } \\
\text { Posttest }\end{array}$ & Mean & $\begin{array}{c}\text { Std. } \\
\text { Deviation }\end{array}$ & $Z$ & $\begin{array}{c}\text { Asymp. Sig. } \\
\text { (2-tailed) }\end{array}$ \\
\hline $\mathrm{X} 1$ & $\begin{array}{c}4.5161 \\
84.5161\end{array}$ & $\begin{array}{c}9.25156 \\
8.09885\end{array}$ & $-5.008^{\mathrm{a}}$ & .000 \\
\hline $\mathrm{X} 2$ & 2.1875 & 6.08243 & $-4.980^{\mathrm{a}}$ & .000 \\
\hline $\mathrm{X} 3$ & 1.0000 & 4.02578 & $-4.832^{\mathrm{a}}$ & .000 \\
\hline
\end{tabular}

Pada kelas X1, kelas X2, dan kelas X3 nilai sig. < 0.05 , hal ini berarti terdapat peningkatan kemampuan multi representasi siswa.
3) Perbedaan Peningkatan Kemampuan Multi Representasi Siswa

Uji perbedaan peningkatan kemampuan multi representasi setelah pembelajaran siswa menggunakan n-gain kemampuan multi representasi tiap kelas menggunakaan uji Mann-Whitney $\mathrm{U}$ dengan taraf signifikansi $\alpha=0.05$ (2-tailed) .

Pada kelas X1 dan X2; kelas X1 dan X3; kelas $\mathrm{X} 2$ dan X3 memiliki nilai sig. > 0.05, hal ini berarti tidak terdapat perbedaan peningkatan kemampuan multi representasi siswa pada kelas yang satu dengan kelas yang lain.

Tabel 4 Hasil Uji U Mann-Whitney pada n-gain

\begin{tabular}{|c|c|c|c|c|c|}
\hline Sampel & Mean & $\begin{array}{c}\text { Std. } \\
\text { Deviation }\end{array}$ & $\begin{array}{c}\text { Mann- } \\
\text { Whitney } \\
\text { U }\end{array}$ & $Z$ & $\begin{array}{c}\text { Asymp. } \\
\text { Sig. } \\
(2- \\
\text { tailed })\end{array}$ \\
\hline $\begin{array}{c}N \text {-gain } \\
\mathrm{X} 1 \text { dan } \\
\mathrm{X} 2\end{array}$ & $\begin{array}{l}.7656 \\
1.51\end{array}$ & $\begin{array}{l}.09993 \\
.504\end{array}$ & 456.000 & -.555 & .579 \\
\hline $\begin{array}{c}N \text {-gain } \\
\mathrm{X} 1 \text { dan } \\
\mathrm{X} 3\end{array}$ & $\begin{array}{l}.7821 \\
1.98\end{array}$ & $\begin{array}{c}.08083 \\
1.008\end{array}$ & 444.500 & -.298 & .766 \\
\hline $\begin{array}{c}N \text {-gain } \\
\mathrm{X} 2 \text { dan } \\
\mathrm{X} 3\end{array}$ & $\begin{array}{l}.7668 \\
2.48\end{array}$ & $\begin{array}{l}.09448 \\
.504\end{array}$ & 402.500 & $1 . \overline{-}$ & .273 \\
\hline
\end{tabular}

Heuvelen \& Zou (2001); Meltzer (2005); Kohl \& Finkelstein (2008; 2007; 2006; 2005) menyatakan bentuk dari kemampuan multi representasi fisika adalah kemampuan untuk menyelesaikan masalahmasalah fisika dengan proses representasi yang bermacam cara yaitu matematis, verbal (tulisan atau oral), dan visual (simbol/notasi, gambar, dan grafik). Kemampuan multi representasi siswa diperoleh dari tes kemampuan multi representasi fisika pada materi kalor yang terdiri dari 9 indikator yang dijabarkan dalam 18 soal essay dengan menggunakan taksonomi Bloom baru (direvisi oleh Anderson \& Krathwoll) dari $\mathrm{C}_{4}$ (menganalisis) sampai $\mathrm{C}_{6}$ (mencipta).

Tes dilakukan sebanyak dua kali, yaitu tes awal (pretest) dan tes akhir (posttest). Nilai pretest digunakan untuk mengetahui kemampuan multi representasi awal siswa sebelum pembelajaran menggunakan perangkat pembelajaran fisika model inkuiri terbimbing. Nilai posttest yang diperoleh siswa menggambarkan tentang penguasaan kemampuan multi representasi siswa setelah mengikuti pembelajaran model inkuiri terbimbing dapat diketahui tentang ada tidaknya peningkatan dari perangkat dengan model inkuiri terbimbing yang diterapkan pada materi kalor. Peningkatan kemampuan multi representasi dapat dilihat dari n-gain dari ketiga kelas replikasi. $\mathrm{N}$-gain rata-rata dari kelas $\mathrm{X} 1, \mathrm{X} 2$, dan X3 adalah sebesar $0.78,0.75$, dan 0.78 dengan kategori tinggi (Hake, 1999). Peningkatan yang ditunjukkan oleh hasil analisis dengan menggunakan n-gain ini menunjukkan tentang penerapan dari pengembangan 
perangkat pembelajaran fisika model inkuiri terbimbing efektif dalam meningkatkan penguasaan kemampuan multi representasi fisika pada materi kalor. Dari ketiga replikasi menunjukkan konsistensi dari perangkat pembelajaran model inkuiri yang dikembangkan untuk melatihkan kemampuan multi representasi. Pembelajaran inkuiri terbimbing memberi kesempatan para siswa membangun pengetahuan secara multi representasi dan membantu siswa mengembangkan pemahaman konsep (Pandey, et al., 2011; Stricklyn, 2011; Lee, et al., 2010; Minner, et al., 2010; Wilson, et al., 2010; dan David, 2006).

Ada beberapa siswa yang tes pengetahuannya tidak tuntas, ternyata tes kemampuan multi representasi juga tidak tuntas. Hal ini dimungkinkan peserta didik yang pemahamannya kurang mengenai suatu konsep maka akan mengalami kesulitan dalam mengerjakan soal yang berbentuk multi representasi. Lebih jauh lagi siswa sangat membutuhkan konsepkonsep untuk mengartikan dan menghubungkan antara masing-masing representasi yang mana ini adalah elemen penyusun dari kemampuan multi representasi (Ainsworth, 2008; 1999; Cheng \& Gilbert, 2007; Chittleborough \& Treagust, 2008; Cook, 2006; Meij \& Jong, 2006). Solusi bagi siswa yang masih kurang adalah pembelajaran remedial secara efektif dalam pembelajaran untuk mengaktifkan kemampuan belajar fisika yang bermakna.

Berdasarkan hasil tiga replikasi ditemukan bahwa kemampuan menyelesaikan masalah menggunakan representasi verbal masih kurang maksimal. Hasil penelitian ini relevan dengan PISA dan Trends in Mathematics and Science Study (2011) dan Programme for International Student Assessment (2009) yang mengisyaratkan bahwa kemampuan siswa Indonesia dalam bidang sains masih rendah, salah satunya menyelesaikan masalah secara multi representasi. Hal tersebut menjadi permasalahan yang pokok dalam pembelajaran sains di Indonesia. Oleh karena itu guru harus mengimplementasikan kurikulum 2013 secara holistik agar pembelajaran bisa menyentuh elemen dasar dari setiap komponen mata pelajaran yang akan dibahas dalam pembejaran.

Ditemukan juga masih ada beberapa siswa yang belum tuntas kemampuan multi representasi. Hal tersebut sejalan dengan hasil penelitian Cook (2006); Jong, et al. (2010); Larkin \& Simon (1987); Meij \& Jong (2006) yang menyimpulkan siswa harus memperoleh pemahaman konsep dan membutuhkan kegiatan pembelajaran yang dapat menyajikan konsep yang mereka miliki secara utuh dengan multi representasi matematis, visual, dan verbal (multi representasi) sehingga berhasil dalam pencapaian kompetensi yang diinginkan. Hal tersebut sesuai dengan respon mereka yang menyatakan kesulitan mengerjakan dan kurang yakin ketika mengerjakan soal tes multi representasi.Pada kenyataannya kesulitan yang mereka alami dikarenakan selama pembelajaran mereka tidak melakukan aktivitas yang relevan dengan skenario pembelajaran yang telah dikembangkan oleh peneliti. Mereka tidak aktif dan lebih dominan dalam aktivitas yang tidak relevan, selain itu mereka merasa sangat kesulitan dalam merepresentasikan konsep yang abstrak. Pada tujuan pembelajaran yang tidak tuntas diberikan solusi remedial dengan pendampingan pembelajaran agar mampu memvisualkan dan merepresentasikan secara verbal dalam proses memahami konsep dalam pembelajaran yang bermakna. Siswa yang mampu merepresentasikan dengan memvisualkan konsep abstrak lebih mudah untuk memahami konsep kalor dari pada siswa yang masih belum ahli (Kautz, et al., 2005; Meltzer, 2004; Loverude, 2002).

Solusi yang memungkinkan untuk diterapkan dalam rangka mencapai ketuntasan indikator bagi siswa yang masih lemah dalam kemampuan multi representasi adalah memberikan lebih banyak soal yang berkaitan, siswa memperoleh pemahaman konsep fisika yang kontekstual melalui kegiatan multi representasi, dan bimbingan guru selama pembelajaran harus lebih intensif bagi siswa yang memiliki kecepatan belajar yang masih rendah. Hasil penelitian Kohl \& Finkelstein (2008) menyimpulkan bahwa siswa belum ahli masih membutuhkan bimbingan untuk menggunakan multi representasi khusus dalam membangun deskripsi verbal dan visual dari suatu masalah untuk dikonversikan menjadi representasi matematis.

Respon siswa yang menonjol dan terekam selama pembelajaran adalah siswa merasa sangat perlu bimbingan guru dalam pembelajaran ketika mereka mengalami kesulitan yang khususnya pada materi baru dan bersifat abstrak. Hal tersebut menjadi bukti nyata dan memperkuat bahwa model inkuiri terbimbing mampu untuk mengajarkan kemampuan multi representasi melalui bimbingan ke siswa yang belum ahli. Penggunaan multi representasi berperan penting dalam membantu siswa membangun pemahaman dengan lebih mudah dan lebih baik, karena konsep yang kompleks dan luas dapat disajikan lebih sederhana dan holistik (Ainsworth, 2006; 1999; Ainsworth, et al., 2002; Ainsworth \& Loizou, 2003; Ainsworth \& Labeka, 2004).

Hasil analisis statistik inferensial dilakukan untuk mengetahui kemampuan multi representasi siswa setelah pembelajaran menggunakan perangkat pembelajaran fisika model inkuiri terbimbing yang telah dikembangkan oleh peneliti. Berdasarkan tinjauan data untuk uji normalitas diperoleh bahwa data tidak berdistribusi normal, jadi analisis statistik 
yang digunakan berupa analisis statistik inferensial non parametrik (uji Mann-Whitney U dan Wilcoxon).

Kemampuan multi representasi awal siswa dianalisis dari data pretest kemampuan multi representasi pada uji Mann-Whitney U dengan taraf signifikansi $\alpha=0.05$ (2-tailed). Pada kelas X1 dan X2; kelas X2 dan X3; kelas X1 dan X3 mempunyai nilai sig. $>0.05$, hal ini berarti tidak terdapat perbedaan kemampuan multi representasi awal siswa pada kelas yang satu dengan kelas yang lain. Hal tersebut menunjukkan bahwa siswa memiliki kemampuan multi representasi yang sama pada awa pembelajaran multi representasi.

Peningkatan kemampuan multi representasi siswa dianalisis dari data pretest dan posttest kemampuan multi representasi tiap kelas (X1, X2, dan X3) menggunakaan uji Wilcoxon dengan taraf signifikansi $\alpha=0.05$ (2-tailed). Pada kelas X1, kelas X2 dan kelas $\mathrm{X} 3$ nilai sig. $<0.05$, hal ini berarti adanya peningkatan kemampuan multi representasi siswa secara signifikan pada materi kalor untuk setiap kelas setelah menggunakan perangkat pembelajaran fisika model inkuiri terbimbing.

Hasil uji perbedaan peningkatan kemampuan multi representasi setelah pembelajaran siswa menggunakan $n$-gain kemampuan multi representasi tiap kelas menggunakaan uji Mann-Whitney U dengan taraf signifikansi $\alpha=0.05$ (2-tailed) pada Lampiran 2x. Pada kelas X1 dan X2; kelas X1 dan X3; kelas X2 dan X3 memiliki nilai sig. $>0.05$, hal ini berarti tidak terdapat perbedaan peningkatan kemampuan multi representasi siswa pada kelas yang satu dengan kelas yang lain.

Hasil uji Mann-Whitney U digunakan untuk mengetahui apakah ada perbedaan yang signifikan dari peningkatan kemampuan multi representasi siswa SMA dikelas X1, X2, dan X3. Hasilnya menunjukkan bahwa tidak ada perbedaan signifikan peningkatan kemampuan multi representasi siswa SMA dikelas X1, $\mathrm{X}$ 2, dan X3. Hal tersebut bisa terjadi dimungkinkan karena guru sudah mengimplementasikan perangkat pembelajaran yang dikembangkan secara maksimal. Tidak ada perbedaan peningkatan kemampuan siswa disebabkan oleh peran guru dalam mendesain pembelajaran dan aktivitas siswa sudah maksimal dalam pembelajaran (Axford, et al., 2009).

Berdasarkan hasil ketuntasan indikator pembelajaran, $n$-gain, analisis statistik non parametrik, aktivitas siswa dan respon siswa menunjukkan tentang penerapan dari pengembangan perangkat pembelajaran fisika model inkuiri terbimbing efektif dalam melatihkan kemampuan multi representasi fisika pada materi kalor. Model inkuiri terbimbing (guided inquiry) diartikan sebagai salah satu model pembelajaran inkuiri yang penyajian masalah, Pengembangan Perangkat Pembelajaran Fisika Model Inkuiri Terbimbing untuk.. pertanyaan dan materi atau bahan penunjang ditentukan oleh guru. Bimbingan dalam bentuk masalah, pertanyaan, dan analogi ini yang mendorong siswa melakukan penyelidikan untuk menentukan jawabannya (Acevedo, et al., 2010; Bao, et al., 2009). Vygostky menyatakan bahwa anak-anak mengembangkan konsep-konsep yang lebih sistematis, logis, dan rasional yang merupakan hasil dari dialog bersama pembimbing yang terampil (Yu, et al., 2013; Zydney, 2010; dan Yu, 2009).

Pembelajaran dengan menggunakan perangkat pembelajaran inkuiri terbimbing menitikberatkan pada kegiatan penyelidikan dengan interaksi sosial, latihan dan tugas-tugas mengenai kemampuan multi representasi fisika pada materi kalor, dan bimbingan guru melalui pertanyaan dan analogi. Hal tersebut sesuai dengan teori kontruktivisme oleh Vygotsky yang mempunyai tiga implikasi utama dalam pembelajaran, yaitu: 1) Melalui interaksi sosial siswa menjadi sadar fungsi mental dasarnya dan mampu menggunakannya untuk pertumbuhan; 2) Guru memberikan tugas-tugas dalam jangkauan siswa (zone of proximal development); dan 3) Memberikan pembelajaran dengan scaffolding (Arends, 2012). Melatihkan kemampuan multi representasi dapat dilakukan pada tiap tahap model inkuiri (Maliyah, dkk., 2012).

Pada perangkat pembelajaran model inkuiri terbimbing yang dikembangkan oleh peneliti juga menggunakan pertanyaan dan analogi sebagai bimbingan saat kegiatan eksperimen dan penyelidikan untuk melatihkan kemampuan multi representasi. Analogi dan pertanyaan akan menjadi bimbingan bagi siswa belum ahli untuk melatihkan kompetensi yang diharapkan (Yu, et al., 2013; Melero, et al., 2012; Zydney, 2010; dan Yu, 2009). Kemampuan siswa dalam multi representasi sangat penting karena siswa dapat meningkatkan pemahaman konsep fisika bila siswa dapat menyajikan dengan multi representasi konsep fisika yang miliki (Kohl, Rosengrant \& Finkelstein, 2007; Rosengrant, Van Heuvelen \& Etkina, 2008; dan Meij, 2007). Pembelajaran inkuiri terbimbing dapat melatihkan kemampuan multi representasi. Hasil penelitian pengembangan perangkat ini diperkuat oleh Putri dkk. (2012) dan Mahardika, dkk. (2012) yang menyimpulkan model inkuiri dapat meningkatkan kemampuan multi representasi dan hasil belajar fisika siswa SMA. Pembelajaran inkuiri terbimbing pada materi suhu dan kalor menggunakan metode eksperimen dan demonstrasi diskusi membutuhkan kemampuan multi representasi yang berpengaruh terhadap prestasi belajar (Maliyah, dkk., 2012).

IV. KESIMPULAN 


\section{A. Simpulan}

Berdasarkan hasil analisis, diskusi, dan pembahasan, maka dapat dibuat kesimpulan bahwa perangkat pembelajaran fisika model inkuiri terbimbing yang dikembangkan sudah valid, praktis, dan efektif untuk melatihkan kemampuan multi representasi siswa SMA.

\section{B. Saran}

Saran dapat dikemukakan oleh peneliti berdasarkan penelititan yang telah dilakukan adalah Pengembangan perangkat pembelajaran model inkuiri terbimbing dapat melatihkan kemampuan multi representasi fisika siswa SMA pada materi kalor sehingga diharapkan untuk penelitian lanjutan pada materi fisika yang lain dan dilengkapi dengan media pembelajaran yang lebih memudahkan siswa memvisualkan konsep-konsep yang abstrak

\section{REFERENSI}

Abdurrahman, Liliasari, Rusli, A. dan Bruce, W. (2011). "Implementasi pembelajaran berbasis multi representasi untuk peningkatan penguasaan konsep fisika kuantum". Cakrawala pendidikan. Vol.30 No.1, pp. 3045.

Acevedo, N. A. Van Dooren, W. Clarebout, G. Elen, J. and Verschaffel, L. (2010). "Representational flexibility in linear-function problems: a choice/no-choice study". In L. Verschaffel, E. De Corte, T. de Jong and J. Elen (Eds.) Use or representations in reasoning and problem solving: Analysis and improvement, 74-79. Milton Park, UK: Routledge.

Ainsworth, S. (2006). "DeFT: A conceptual framework for considering learning with multiple representations". Learning and instruction. Vol.16 No.3, pp. 183-198. (1999). "The Functions of Multiple Representations". Computers and Education. Vol. 33 No. 1, pp. 131-152.

Ainsworth, S. and Van Labeke, N. (2004). "Multiple forms of dynamic representation". Learning and instruction. Vol.14 No.1, pp. 241-255.

Ainsworth, S. and Loizou, A. (2003). "The effects of self-explaining when learning with text or diagrams". Cognitive science. Vol. 27 No.1, pp. 669-681.

Akbulut, Y. (2007). "Implications of two well-known models for instructional designers in distance education: Dick-Carey versus Morrison-RossKemp". Journal of distance educationTODJOE Anadolu University. Vol.8 No.2, pp. 5.

Arends, R. (2012). Learning to teach, 9th edition. New York: Mc-Graw Hill.

Arifin, Z. (2009). Evaluasi pembelajaran. Bandung: PT Remaja Rosda Karya.
Ashiq H. A., Muhammad, A., and Azra, S. (2011). "Physics teaching methods: scientific inquiry vs traditional lecture". International journal of humanities and social science. Vol.1 No.19, pp. 269-276.

Axford, B., Harders, P., and Wise, F. (2009). Scaffolding literacy. An integrated and sequential approach to teaching reading, spelling and writing. Australia: Acer Press.

Bao, L. Fang, K. Cai, T. Wang, J. Yang, L. Cui, L. Han, J. Ding, L. and Luo, Y. (2009). "Learning of content knowledge and development of scientific reasoning ability: A cross culture comparison". American journal of physics. Vol.77 No.12, pp. 1118-1123.

Berg, C. A. R. Bergendahl, V. C. B. and Lundberg, B. K. S. (2003). "Benefiting from an open-ended experiment? A comparison of attitudes to, and outcomes of, an expository versus an openinquiry version of the same experiment". International journal of science education. Vol.25 No.3, pp. 112-121.

Belland, B. R. Walker, A. Olsen, W. and Leary, H. (2012). "Impact of scaffolding characteristics and study quality on learner outcomes in STEM education: A meta-analysis". Paper presented at the AERA annual convention, Vancouver, British Columbia, Canada, 2012.

Benckert dan Pettersson. (2008). "Learning physics in small-group discussions- there examples". Eurasia journal of matematics, science, and technology education. Vol.2 No.1, pp. 121134

Borich, G. (1994). Observation skill for effective teaching. New York: Mac Millan Publishing Company.

Branch, J. and Oberg, D. (2004). Focus on inquiry a teacher guide to implementing inquiry based learning. Canada: Alberta Education, Alberta.

Bryce, D. (2012). "Scaffolding in Teaching Knowledge Representation". Present at CCSC: Rocky Mountain Conference, Utah State University

Changbalengula, Mumba, dan Mbewe. (2012). "How pre-service teachers' understand and perform science process skills". Journal of research in science teaching. Vol.22 No.4, pp. 167-176.

Cheng, M. and Gilbert. (2009). "Towards a better utilization of diagram in research into the use of representative levels in chemical education. model and modeling in science education: Multiple representations in chemical education". Springer Science+Business Media B.V. p. $55-73$.

Chittleborough, G. and Treagust, D. (2008). "Correct interpretation of chemical diagrams requires transforming from one level of representation to another". Research in science education. Vol.38 No.4, pp. 463-482.

Coletta, V. P. Phillips, J. A. and Steinert, J. (2012). "FCI Normalized Gain, Scientific Reasoning Ability, Thinking in Physics, and Gender Effects" Present at AIP Conf. Proc. LA, 2012. 
Cook, M. (2006). "Visual representations in science education: The influence of prior knowledge and cognitive load theory on instructional design principles". Science Education. Vol.90 No.6, pp. 1073-1091.

Crawford, B. A. (2000). "Embracing the essence of inquiry: new roles for science teachers". Journal of research in science teaching. Vol.37 No.9, pp. 916-937.

Crockett, M. D. (2002). "Inquiry as professional development: creating dilemmas through teachers' work". Teaching and teacher education. Vol.18 No.5, pp. 609-624.

David, M. J. Christophe, D. J. Norma, A. J. (2013). "The effect of representations on difficulty perception and learning of the physical concept of pressure". Themes in science and technology education. Vol.6 No.2, pp. 91108.

De Jong, T. (2010). Cognitive load theory, educational research, and instructional design: Some food for thought. Instructional science. Vol.38 No.3, pp. 105-134.

Dolin, J. (2001). "Representational forms in physics" Paper presented at Third International Conference of the European Science Education Research Association, August, 2001.

Eisenkraft, A. (2010). Active Physics. New York: It's About Time.

Etkina, E. (2006). "Scientific abilities and their assessment". Physical review special topicsPhysics education research. Vol.2 No.3, pp. 20-29.

Fellenz, M. R. (2004). "Using assessment to support higher level learning: the multiple choice item development assignment". Assessment and education in higher education. Vol.29 No.6, pp. 703-719.

Fu, Y. Han C. T. and Hui, L. W. (2013). "Effects of online procedural scaffolds and the timing of scaffolding provision on elementary taiwanese students' question-generation in a science class". Australasian journal of educational technology. Vol.29 No.3, pp. 8998.

Gerald, F. L. (2011). "The twin purposes of guided inquiry: guiding student inquiry and evidence based practice". Scan. Vol 30 No 1. pp. 2641.

Gilbert, K. J. (2010). "The role of visual representations in the learning and teaching of science: An introduction". Asia-pacific forum on science learning and teaching. Vol.11 No.1, pp. 1-10.

Gronlund, N. E. and Linn, R. L. (1995). Measurement and assesment in teaching (7th ed). New Jersey: Merril Englewood Cliffs.

Gunel, M. et al. (2006). "Comparing student understanding of quantum physics when embedding multimodal representations into two different writing formats: Presentation format versus summary report format".
Science education. Vol.90 No.10, pp. 10921112.

Hake. (1999). Analyzing change/gain scores. (Online). Tersedia http://www. physicsindiana.edu/sdi/Analyzing-ChangeGain. pdf.

Harrison, A. and De Jong, O. (2005). "Exploring the use of multiple analogical model when teaching and learning chemical equilibrium. Journal of research in science teaching. Vol.42 No.9, pp. 1135-1159.

Heron, P. R. L. and Meltzer, D. E. (2005). "Future of physics education research: Intellectual challenges and practical concerns". American journal of physics. Vol.73 No.5, pp. 390-394.

Heuvelen, V. and Zou. X. L. (2001). "Multiple representations of work-energy processes". American journal of physics. Vol.69 No.2, pp. 184.

Izhak and Sherin, M. G. (2003). "Exploring the Use of New Representation as a Resource for Teaching Learning". Journal school science and mathematics. Vol.20 No.1, pp. 103.

Kementerian Pendidikan dan Kebudayaan. (2013). Modul pelatihan implementaasi kurikulum (2013). Jakarta: Badan Pengembangan Sumber Daya Manusia Pendidikan dan Kebudayaan dan Penjaminan Mutu Pendidikan.

Kemp, J. E. and Morison. (2007). Designing effective instruction. New York: Macmillan College Publishing Company.

Khan, M. S. Hussain, A. R. Majoka, M. I. and Ramzan, M. (2011). "Effect of inquiry method on achievement of students in chemistry at secondary level". International journal of academic research. Vol.3 No.1, pp. 955-959.

Kirschner, P. A. Sweller, J. and Clark, R. E. (2006). "Why minimal guidance during instruction does not work: an analysis of the failure of constructivist, discovery, problem-based, experiential, and inquiry based teaching". Educational psychologist. Vol.41 No.2, pp. 75-86.

Kohl, P.B. and Noah, D.F. (2008). "Pattern of multiple representation use by expert and novices during physics problem solving". Physical review special topics-Physics education research. Vol.4 No.1, pp. 1-13.

Kohl, P.B. and Noah, D.F. (2006). "Effect of representational on students solving physics problem : A fine-grained characterization". Physical review special topics-Physics education research. Vol.2 No.1, pp. 1-8.

Kress, G. Jewitt, C. Ogborn, J. Tsatsarelis, C. (2003). "Exploring learning through visual, actional and lingusitic communicaion: The multimodal environment of a science classroom". Educational Review. Vol.53 No.1, pp. 120127. 
Kuhlthau, C. C. Maniotes, L. K. and Caspari, A. K. (2012). Guided inquiry design. Libraries Unlimeted:Imprint ABC.

Kuhlthau, C.C. (2010). "Guided inquiry". School libraries worldwide. Vol.16 No. 1, pp. 17-28.

Larkin, J. and Simon, H. (1987). "Why a Diagram is (sometimes) worth ten thousand words". Cognitive Science. Vol.11 No.1, pp. 65-99.

Lee, H. Linn, M. Varma, K. and Liu, O. (2010). "How do Technology-Enhanced Inquiry Science Units Impact Classroom Learning". Journal of research in science teaching. Vol.47 No.1, pp. 71-90.

Lu, L. and Ortlieb. E. T. (2009). "Teacher candidates as innovative change agents". Current issues in education. Vol.11 No.5, pp. 111-119.

Luft, J. (2001). "Changing inquiry practices and beliefs: The impact of an inquiry-based professional development programs on beginning and experienced secondary science teachers". International journal of science education. Vol.23 No.5, pp. 517-534.

Loverude, M. Kautz, C. and Heron, P. (2002). "Student understanding of the first law of thermodynamics: relating work to the adiabatic compression of an ideal gas." American journal of physics. Vol.70 No.2, pp. 137-48.

Madden, K. (2011). "The use of inquiry-based instruction to increase motivation and academic success in a high school biology classroom". (PDF). Retrieved April 30, (2014) from Montana State University library.

Mahardika K . I. Agus, S. dan Dadi, R. (2012). "Model inkuiri untuk meningatkan kemampuan representasi verbal dan matematis pada pembelajaran fisika di SMA". Jurnal pembelajaran fisika. Vol.1 No.2, pp. 165-171.

Mahardika, K. I. (2012). Karakteristik bahan ajar mekanika (BAM) untuk meningkatkan kemampuan representasi verbal, matematis, gambar, dan grafis (VMG2) mahasiswa calon guru fisika. (Disertasi Doktor pendidikan tidak dipublikasikan). Universitas Pendidikan Indonesia.

McDonald, E. K. (2009). Engage every student. Motivation tools for teachers and Parent. USA: Search institute.

Minner, D. Levy, A. and Century, J. (2010). "Inquiry based science instructions-what is it and does it matter? results from a research synthesis years 1984 to 2002". Journal of research in science teaching. Vol.47 No.2, pp. $474-496$.

Muliyardi. (2008). Pengembangan model pembelajaran matematika dengan menggunakan komik di kelas 1 SD. (Disertasi Doktor tidak dipublikasikan). Universitas Negeri Surabaya.

Maliyah, N. dkk. (2012). "Pembelajaran fisika dengan inkuiri terbimbing melalui metode eksperimen dan demontrasi diskusi ditinjau dari kemampuan matematik dan kemampuan verbal siswa". Jurnal Inkuiri. Vol.1 No.3, pp. 227-234

Mayer, R .(1997). Multimedia learning: Are we asking the right questions". Educational Psychologist. Vol.32 No.2, pp. 1-19.

Mayer, R. (2001). Multimedia learning. New York: Cambridge University Press.

Mayer, R. E. (2003). "The promise of mulitmedia learning: Using the same instructional design methods across different media". Learning and instruction. Vol.13 No.3, pp. 125- 139.

Mayer, R. (2005). The cambridge handbook of multimedia learning. Cambridge: Cambridge University Press.

McDermott, L. C. Heron, P. R. L. Shaffer, P. S. and Stetzer, M. R. (2006). "Improving the preparation of k-12 teachers through physics education research". American journal of physics. Vol.74 No.9, pp. 763-767.

McDermott, L. C. (2004). Physics by inquiry [Online]. Tersedia:

http://www.phys.washington.edu/RGoups/peg /pbi.html.

Meij, J. and Jong, T. (2007). Learning with multiple representations. Paper presented at the EARLI Conference, Padua, Italy, 26 August, 2007.

Meij, J. and Jong, T. (2006). "Supporting students' learning with multiple representations in a dynamic simulation-based learning environment". Learning and instruction. Vol.16 No.3, pp. 199-212.

Meltzer, D. E. (2005). "Relation between students' problem-solving performance and representational format". American journal of physics. Vol.73 No.5, pp. 463.

Mercer, N. Dawes, L. Wegerif, R. and Sams, C. (2004). Reasoning as a scientist: ways of helping children to use language to learn science. British educational research journal. Vol.30 No.3, pp. 359-377.

Michal, Z. (2007). "The spectrum of dynamic inquiry teaching practices". Research Science Education. Vol.3 No.2, pp. 59-67.

Ministrell, J. and Kraus, P. (2005). "Guided Inquiry in the Scinece Classroom". In Donovan, M. S and Bransford, J.D. How students learn: history, mathematics, science in the classroom, 475-513. Washington: The National Press.

Moreno, R. and Durán, R. (2004). "Do multiple representations need explanations? The role of verbal guidance and individual differences in multimedia mathematics learning". Journal of educational psychology. Vol.96 No.3, pp. 492-503.

Nieminen, P., Savinainen, A. and Viiri, J. (2013). "Representational consistency and the learning of forces in upper secondary school physics”. Jyväskylä: Jyväskylä University Printing House.

Nieminen, P. Savinainen, A. and Viiri, J. (2012). "Relations between representational 
consistency, conceptual understanding of the force concept, and scientific reasoning". Physical review special topics - Physics education research. Vol.8 No.1, pp. 11-23.

Nieminen, P. Savinainen, A. Nurkka, N.and Viiri, J. (2011). An intervention for using multiple representations of mechanics in upper secondary school courses, in Proceedings of the ESERA (2011) Conference, Lyon, 2011.

Pandey1, G. K. Nanda, and Ranjan, V. (2011). "Effectiveness of inquiry training model over conventional teaching method on academic achievement of science students in India" Journal of innovative research in education. Vol.1 No.1, pp. 7-20.

Prahani, B. K. Rachmadani, D. dan Paramartha, A, I. (2014). "Optimalisasi hasil belajar ipa melalui pengembangan perangkat pembelajaran IPA terpadu tipe webbed". Prosiding Seminar Nasional Pendidikan Sains (2014), Surabaya, 2014.

Putri, M. A. Mahardika, dan Ketut. (2012). "Model pembelajaran free inquiry (inkuiri bebas) dalam pembelajaran multirepresentasi fisika di MAN 2 Jember". Jurnal pembelajaran fisika. Vol.1 No.3, pp. 324-327.

Ratumanan, G. T. dan Laurens. (2011). Evaluasi hasil belajar pada tingkat satuan pendidikan. Surabaya: Unesa Unversity Press.

Riduwan. (2010). Skala pengukuran variabel-variabel penelitian. Bandung: Alfabeta.

Rosengrant, D. Van Heuvelen, A. and Etkina, E. (2006). "Two year study on students' use of free-body diagrams". Paper present at NARST Annual Meeting, San Francisco, CA, 2006.

Rosengrant, D. Van Heuvelen, A. and Etkina, E. (2009). "Do students use and understand freebody diagrams?". Physical review special topics-Physics education research. Vol.5 No.1, pp. 1-8.

Rust, P. (2011). The effects of inquiry instruction on problem solving and conceptual knowledge in a ninth grade physics class. (PDF). Retrieved April 30, (2014) from Montana State University Library.

Schnotz, W. Baadte, C. Müller, A. and Rasch, R. (2010). Creative thinking and problem solving with depictive and descriptive representations. In L. Verschaffel, E. De Corte, T. de Jong and J. Elen (Eds.), Use of representations in reasoning and problem solving: Analysis and improvement (pp. 1135). Milton Park, UK: Routledge.

Schnotz, W. and Lowe, R. (2010). "External and internal representations in multimedia learning". Learning and instruction Vol.13 No.3, pp. 117- 123 .
Schnotz, W. and Lowe, R. (2003). "Special issue introduction: External and internal representations in multimedia learning". Learning and instruction. Vol.13 No.2 116122.

Schnotz, W., and Bannert, M. (2003). "Construction and interference in learning from multiple representation". Learning and instruction, 13(2).

Seufert, T. (2003). "Supporting coherence formation in learning from multiple representations". Learning and instruction. Vol.13 No.3, pp. 227-237.

Stricklyn, J. (2011). What effect will using inquiry methods of teaching science have on sixth grade students?. Montana State University Library.

Sugiyono. (2014). Metode penelitian kombinasi (mixed methods). Bandung: ALFABETA.

Trilling, B dan Fadel, C. (2009). 21st century skills: learning for life in our times. USA: JosseyBass.

Waldrip, B. Prain, V. and Carolan, J. (2010). "Using multi-modal representations to improve learning in junior secondary science". Res. science education. Vol.40 No.1, pp. 65-80.

Waldrip, B. Prain, V. and Carolan, J. (2006). "Learning junior secondary science through multi-modal representations". Electronic journal of science education. Vol.11 No.1, pp. 86-105.

Wenning, C. J. (2011). "Experimental inquiry in introductory physics courses" .JPTEO (Journal of Physics Teacher Education Online) Illinois State University Physics Dept. USA. Vol.6 No.2, pp. 7.

Wilson, C. D. Taylor, J. A. Kowalski, S. M. and Carlson, J. (2010). "The relative effects and equity of inquiry-based and commonplace science teaching on students' knowledge, reasoning, and argumentation". Journal of research in science teaching. Vol.47 No.5, pp. $276-301$

Yoshioka, D. (2007). Statical physics an introduction. German: Springer.

Yu, F. Y. (2009). "Scaffolding student-generated questions: Design and development of a customizable online learning system". Computers in human behavior. Vol.25 No.5, pp. 1129-1138.

Zydney, J. M. (2010). "The effect of multiple scaffolding tools on students' understanding, consideration of different perspectives, and misconceptions of a complex problem". Computers and education. Vol. 54 No.3, pp. 150-159. 